\title{
CSALÁDBŐVÍTÉSI INTENCIÓK - A HARMADIK GYERMEK VÁLLALÁSÁNAK SZÁNDÉKA
}

\section{Árki Diána}

\section{ÖSSZEFOGLALÓ}

A tanulmány a paritás-specifikus termékenységi döntések folyamatának vizsgálatára, mindenekelőtt a harmadik gyermek vállalására irányuló szándék közelebbi megértésére törekszik. A felvázolt elméleti keret és az empirikus elemzés révén magyarázatot kaphatunk arra a kérdésre, hogy a kétgyermekes nők mely jellemvonásai befolyásolják a harmadik gyermek világrahozatalának szándékát: Milyen módon hatnak a személyek strukturális pozíciói (1.), értékei (2.), valamint jövőirányultságára utaló nézetei (3.) arra, hogy kívánnak-e az egyének harmadik utódot? Többváltozós elemzésemet logisztikus regressziós módszer alkalmazásával valósitottam meg a KSH Népességtudományi Kutatóintézet, Életünk fordulópontjai társadalmi-demográfiai adatfelvétel első (2001/2) adatfelvételi hullámának felhasználásával. Eredményeim szerint az ezredfordulót követően azok a 30 év alatti, egyház tanításait követő, azonos nemű gyermekeket nevelő nők szerették volna bővíteni családjukat, akik nagyobb településen (Budapesten vagy megyei jogú városban), nem családi házban éltek, és a munka iránt kevésbé elkötelezettek. Mindezek következtében előzetes feltevéseim közül több hipotézisem igazolást nyert, ugyanakkor az eredmények számos feltételezésemet megcáfolták.

Tárgyszavak: termékenységi döntések, harmadik gyermek vállalásának szándéka, logisztikus regresszió, Életünk fordulópontjai

Árki Diána, PhD-hallgató, Pécsi Tudományegyetem, Demográfia és Szociológia Doktori Iskola

E-mail: arki.diana25@gmail.com 


\section{BEVEZETÉS}

Magyarországon az 1980-as évek elejétől megszakadt a természetes szaporodás folyamata, és kezdetét vette a népességszám csökkenése, amelynek legfontosabb kiváltó tényezője a termékenység reprodukciós szint alá süllyedése volt. E kedvezőtlen irányú változások hosszú távon számos - politikai, gazdasági, társadalmi - problémát idéznek elő, amely következményekkel hazánk lakosságának többsége is szembesült: a népesség nagy része szükségesnek tekinti az ország lélekszámának gyarapodását. A magyar társadalomban általánosan elterjedt kétgyermekes családmodell ugyanakkor a népesség egyszerű reprodukciós szintjének biztosítását sem teszi lehetővé. A termékenység javulásához elengedhetetlen, hogy a kétgyermekes szülők nagyobb hányada hozzon világra harmadik utódot, hozzájárulva ezáltal a népesedési helyzet fordulópontjához (S. Molnár - Pongrácz 2002 [1996]: 394), Werner - Middlestadt-Carter - Crawford 1975: 348). Felvetődik a kérdés, miért nem születik több gyermek? Miért nem vállalnak a magyar nők több, legalább három gyermeket?

Tanulmányomban annak vizsgálatára törekedtem, hogy a két, saját gyermeket nevelő anyák mely sajátosságai segítik elő, avagy az egyén mely jellemvonásai hátráltatják a harmadik gyermek vállalásának szándékát. Az Ajzen-Fishbein féle elméletet alapul véve, az intenció erős kapcsolatban áll a viselkedéssel, amelynek okán a gyermekvállalásra irányuló szándék elemzése hozzájárul a termékenységi magatartás mélyebb megértéséhez. Az intenció kutatását mindemellett az az elképzelés indokolta, miszerint a harmadik gyermekre való átmenetben az egyén demográfiai, társadalmi és gazdasági sajátosságai közül a kifejezett szándék képviseli a legnagyobb befolyással bíró faktort (Rinesi 2009, idézi: Régnier-Loilier - Vignoli 2011: 366-367).

A paritás-specifikus megközelítést az a teória alapozta meg, hogy a korábban született gyermekek száma hatást gyakorolhat a szülők reprodukciós döntéshozatali folyamatára, így a szándékok változhatnak az első és második utód világrajövetele, a családtervek újraértékelése után (Beckman 1983, idézi: Rosina - Testa 2009: 489; Heiland - Prskawetz - Sanderson 2008: 14).

Az egyén szándékának a gyermekvállalási gyakorlatban történő felértékelődése következtében az utóbbi évtizedekben számos tanulmány foglalkozott azzal a kérdéssel, hogy milyen tényezők játszanak szerepet a termékenység intenciójának megfogalmazódásában (például Miettinen - Basten - Rotkirch 2011, Spéder - Kapitány 2007, Testa 2010). A harmadik utód világrahozatalának intenciója azonban nem áll sem a nemzetközi, sem a hazai kutatások középpontjában. A harmadszori szülővé válás tényleges cselekvésének esélyét ele- 
mezte ugyan a Spéder - Kapitány (2007) szerzőpáros, az adott paritást azonban nem önmagában, hanem a második gyermek vállalásának kockázatával együtt tárták fel.

Fontosnak tartom megemlíteni továbbá, hogy a „szándék” kifejezést a témakörben végzett kutatások nem azonos értelmü fogalomként használják. Az intenció utalhat egyrészt arra a gyermekszámra, amelyet az egyén élete során szeretne elérni - vagyis jelentheti az összesen áhított gyermek mutatóját, a vágyott családméretet. Másrészt tájékoztathat arról, hogy a gyermektelenek kivánnak-e valaha utódot, míg a már szülővé vált személyek esetében rávilágithat arra, hogy vágynak-e további gyermek(ek) születésére. Mindezen meghatározások az általában vett gyermekvállalási szándékra összpontosulnak: azt szemléltetik, hogy az egyén miképpen tervezi termékenységét az egész életét tekintetbe véve. Emellett viszont alternatívaként megadhatunk egy időkeretet, amely az időzitett intenció alapjául szolgálhat. Lehetőség nyilik ezáltal annak vizsgálatára, hogy a személyek egy adott időtartamon (két, három vagy öt éven) belül hogyan tervezik gyermekvállalási gyakorlatuk megvalósítását vagy éppen elhalasztását (Philipov - Testa 2008: 5, Spéder - Kapitány 2007: 51-52, 56). A harmadik gyermek megszületésére irányuló szándék vizsgálata során kutatásomban nem az „időzített”, hanem az „általános” szándék megértésére törekedtem.

Tanulmányom első részében a témához kapcsolódó elméletek rövid áttekintésére kerül sor. Álláspontom részletezését követően rávilágítok a harmadik gyermek sajátságos helyzetére, majd a termékenységre irányuló szándék és a tényleges viselkedés közötti kapcsolat elméleti kereteit vázolom fel.

A fejlett országokban a gyermekek számának módosulását nem tudjuk egy teóriával megmagyarázni, ezért empirikus elemzésemben a harmadik gyermek vállalásának szándékát is komplex folyamatként közelítem meg, hiszen az intenció szimbolizálja azt a „végső közös utat”, amelyen keresztül a cselekvési összetevők befolyásolják a reproduktív viselkedést (Miller - Pasta 1995, idézi: Rosina - Testa 2009: 488). Fawcett (1983: 359) meglátása alapján a harmadik utód megszületésére irányuló szándéknál egyre fontosabbá válnak a költséghaszon megfontolások, véleményem szerint ugyanakkor számolni kell az értékek és normák, valamint a jövő iránti beállítottság hatásával is. Ma ugyanis „azért cselekszünk - vagy éppenséggel nem cselekszünk -, hogy a holnapi és holnaputáni problémákat ... megakadályozzuk" (Beck 2003 [1986]: 48).

Feltételezésem tesztelését logisztikus regressziós módszer alkalmazásával valósítom meg. E többváltozós statisztikai eljárás lehetőséget nyújt annak 
elemzésére, hogy a két gyermeket nevelő anyák számos jellemvonása közül mely sajátosságok hatnak a harmadszori szülővé válás pozitív szándékára. Az adatok forrása a KSH Népességtudományi Kutatóintézet, Életünk fordulópontjai társadalmi-demográfiai adatfelvétel első adatfelvételi hulláma (2001/2). Egy közel 20 éves adatbázis elemzéséből kétségkívül nem lehet következtetéseket levonni arra vonatkozóan, hogy napjainkban kik azok a kétgyermekes nők, akik harmadik gyermeket szeretnének vállalni. Az adatfelvétel óta eltelt időszakban végbemenő gazdasági változások mellett számos népesedéspolitikai intézkedés született, amelynek célja a harmadik gyermek megszületésének elősegítése volt, így feltételezhetően ma másfajta attitűdökkel rendelkező anyák vágynak inkább harmadik utódra. Az ezredforduló környékén jelenlévő összefüggések feltárása mindazonáltal közelebb vihet minket a termékenységi magatartás megértéséhez.

\section{A HARMADIK GYERMEK VÁLLALÁSÁNAK ELMÉLETI ALAPJAI, KIINDULÓ HIPOTÉZISEK}

A termékenység változásait értelmező közelítések eltérő válaszokat adnak a gyermekszám alakulására. A két világháború közti időszakban megszülető első demográfiai átmenet elmélete a modernizációs folyamatokra, kiváltképp a gazdasági fejlődésre vezette vissza a gyermekvállalási hajlandóság visszaesését - lehetőséget teremtve ezáltal az anyagi tényezők szerepét előtérbe helyező közgazdaságtani nézetek kibontakozására. Az 1960-1970-es évektől realizálódó második demográfiai átmenet már a társadalomban jelen lévő értékek és normák módosulásával indokolta a születésszámokban tapasztalható negatív irányú fordulatot, amely magával vonta a termékenységgel foglalkozó szociológiai elmélet megjelenését is.

A 20. század utolsó évtizedeiben egyre inkább nyilvánvalóvá vált, hogy a termékenység szintjének átalakulását nem lehet csupán az anyagi faktorok megváltozásával, vagy kizárólag az értékrendben történő szemléletváltással igazolni (Dányi 2000: 236).

Lesthaeghe és Moors (2000: 409) gondolatmenete a több szempontú megközelítést emeli ki. Véleményük szerint a demográfiai folyamatokban sem a strukturális, sem a kulturális magyarázat-típusokat nem lehet irrelevánsnak tekinteni. A gyermekszám alakulásának megértéséhez egyaránt számításba kell venni az egyének „társadalmi, gazdasági vagy bármely más pozícióra 
vonatkozó" jellemvonását (azaz strukturális helyzetét), valamint a szülők értékorientációinak sajátosságát is (kulturális körülményeit) - így e kétfajta nézet összeegyeztethető.

A legátfogóbb - több tudományterületet felölelő - keretet Andorka Rudolf szerint Alfred Sauvy dolgozta ki a termékenység változásainak megragadásához. A francia közgazdász-demográfus elképzelésében a szülők anyagi helyzetük mellett gyermekszámra irányuló döntésük elhatározásakor a társadalmi közhangulatot és a jövőre vonatkozó perspektíváikat is szem előtt tartják. Ha jövedelmüket alacsonynak, a társadalom közhangulatát gyermekellenesnek, jövőjüket pedig borúlátóan ítélik meg, akkor kevesebb gyermeket vállalnak a párok. Amennyiben viszont bizakodva fordulnak a jövő felé, anyagi helyzetüket jónak, a társadalmat dinamikusnak tekintik, úgy a magasabb gyermekszám mellett döntenek (Sauvy 1963, idézi: Andorka 2006 [1986]: 293-294).

E két felvetést alapul véve a gyermekvállalást olyan jelenségként értelmezem, amely az egyén objektív, strukturális jellemvonásai, valamint szubjektív beállítódásai összekapcsolódásának eredményeként valósul meg.

Álláspontom szerint e felfogást az indokolja, hogy ma már Európa szerte vitathatatlanná vált az a meggyőződés, miszerint a gyermekvállalás függ a személyes attitüdöktől, a világnézettől, a társadalmi környezettől (Cseh-Szombathy 2000: 12). A gyermekszámra irányuló egyéni értékeket és normákat „erősen befolyásolja az a társadalmi környezet, illetve az a társadalmilag kialakult értékrend, amelyben az emberek élnek, tevékenykednek, mozognak, dolgoznak” (Kamarás 2001: 36).

Nem lehet azonban figyelmen kívül hagyni a gazdasági paraméterek szerepét sem. A gyermek megszületése ugyanis olyan döntés, amelyet „nagyon könnyen negligálhat az anyagi ellenérdekeltség” (Vajda 1990 [1988]: 55). Habár manapság a szülők szinte egyáltalán nem kalkulálnak a gyermekek gazdasági hasznával, a gyermekvállalás ellen ható mutatók között első helyen az anyagi terhek realizálódnak, így nem lehet azt kijelenteni, hogy a gazdasági faktorok semmiféle hatást nem gyakorolnak a termékenység szintjére (Bulatao 1981, idézi: Andorka 1987: 228).

\section{A közgazdaságtani nézőpont}

A gyermekvállalás közgazdaságtani megközelítése ugyanakkor nem ellentmondásoktól mentes. A gazdasági szempontokat figyelembe véve egyrészt megálla- 
pítható, hogy a magasabb jövedelmü háztartásokban kedvezőbb élethelyzetük okán több gyermek felnevelésére nyilik lehetőség. Másrészt a jóléti társadalmakban a többedik gyermek megszületése nem jár együtt a világrajövetelükkel nyert jövedelmi és biztonsági profit növekedésével: a gyermekmunka tilalma és a nyugdijalapok megjelenése okán e tényezők már nem játszanak szerepet a gyermekszámról való döntésben. A többedik gyermekkel járó nyereségek nem, a ráfordítások azonban egyre inkább emelkednek. Minden további gyermeknek szüksége van anyagi támogatásra, így több gyermek több pénzbe és több időbe kerül. A harmadik gyermekről való döntésnél ennek okán egyre inkább a haszonáldozati költségek kerülnek előtérbe, hiszen a sokadik gyermek csekély előnyt biztosít szülei számára. E következtetésekből kifolyólag a magasabb jövedelmü családok kevésbé valószínű, hogy harmadik gyermekre vállalkoznak - minél nagyobb az anya kereseti vesztesége, annál kisebb lesz a családbővítés esélye (Alich 2004: 35-36).

Becker szintén arra hívta fel a figyelmet, hogy a magasabb jövedelmü családok jobb anyagi helyzetükből kifolyólag több gyermeket vállalhatnak - a tapasztalat azonban azt mutatta, hogy nem a jómódú, hanem a rossz anyagi helyzetű családokban születik több gyermek. Ezen tények alapján arra következtetett, hogy a szülők számára a kevesebb, de jobban iskolázott gyermek egyenértékű a több, ellenben kevésbé „minőségi” gyermekkel. E szempontból a magasabb jövedelmú családok többet, míg az alacsonyabb jövedelmüek kevesebbet költenek utódaikra, így előbbiek esetén kisebb, míg utóbbiaknál nagyobb a harmadik gyermek megszületésének valószínüsége (Alich 2004: 37).

A költség-haszon elemzést preferáló közgazdaságtani elmélet ezáltal negatív irányú összefüggést feltételez a harmadik gyermek megszületése és az anya jövedelme között. E teória alapján hasonló viszony áll fenn a többedik gyermek vállalása, valamint az iskolai végzettség mutatója között is, hiszen lineáris kapcsolat fedezhető fel e két tényező esetében: minél magasabb az anya iskolai végzettsége, annál nagyobb lesz a keresete és a harmadik gyermek vállalásának haszonáldozati költsége is (Alich 2004: 36).

A közgazdaságtani megközelítések figyelembevételével kialakitott hipotéziseim:

H1: Az anya iskolai végzettségének emelkedése csökkenti a harmadik utód világrajövetelére irányuló intenció valószínűségét.

H2: Minél kedvezőbb a háztartás jövedelmi helyzete, annál kisebb az esélye a harmadszori anyává válás szándékának. 


\section{A harmadik gyermek mint kockázati tényező}

A termékenység közgazdaságtani elmélete által előtérbe helyezett költséghaszon elemzésből kiindulva, a foglalkoztatott, magas jövedelmű nőknél állásuk későbbi (gyermekszülés utáni) biztonsága miatti aggodalom, a munkahely elvesztésétől való félelem szintén arra motiválhatja a szülőket, hogy korlátozzák tervezett gyermekeik számát - a felesleges kockázatot úgy hárítják el, hogy csökkentik gyermekszámra irányuló eredeti tervüket (S. Molnár - Dobossy 2000: 80). A harmadik gyermek efféle általános elutasítása mögött véleményem szerint az sejthető, hogy az emberek jövőre irányuló elképzeléseik realizálódását veszélyeztető kockázatnak tekintik a többedik gyermek vállalását. A kockázat ugyanis olyan jelenség, amely „mérlegre teszi a hasznot és a károkat, és a jelenben dönthet a jövő felől” (Beck 2008 [1999]: 33).

A munkanélküli, inaktív vagy alacsony jövedelmű családoknál viszont fordított mechanizmus müködik. A társadalom alsó csoportjaiban a harmadik gyermek mint az egyéni életcélok megvalósulását elősegítő eszköz jelenik meg: számukra a kismértékű jövedelemveszteség miatt kisebb haszonáldozati költséggel párosul (Spéder 2003: 89), illetve az álláshiány miatt alacsonyabb kockázattal jár a harmadik gyermek vállalása. Kutatási tapasztalatok alapján legmagasabb valószínűséggel háztartásbeli, illetve munkanélküli nők adnak életet harmadik gyermeküknek, míg foglalkoztatott státusszal lényegesen kisebb erre az esély (Alich 2004: 120-121; Berinde 1999, idézi: Alich 2004: 85; Kravdal 1990: 73-74; Statistics Sweden 2011: 56).

Ezen eredményeket figyelembe véve, hipotézisem a következő:

H3: Legnagyobb eséllyel a nem foglalkoztatott nők szeretnének ismét szülni, míg legkisebb kockázattal a foglalkoztatott pozícióban lévő anyák kívánnak harmadik utódot vállalni.

\footnotetext{
'Meglátásom szerint az effajta cselekvésben a weberi célracionalitás elve érvényesül. A párok cselekvését e perspektívában célok, eszközök és mellékkövetkezmények irányítják, döntésüket pedig mindezen tényezők racionális egybevetése alapján deklarálják (Weber 1987 [1922]: 54). A szülők kitüznek maguk elé egy célt, majd mérlegelik azt, hogy az adott gyermekszám elérése mint eszköz, mennyiben járul hozzá e kulcsfontosságú állapot létrejöttéhez. Amennyiben az adott gyermekszám negatív következményt von maga után, nem vállalják az utódot; míg fordított esetben a gyermek megszületése mellett döntenek.
} 


\section{A harmadik gyermek mint az ideálisnak tartott gyermekszámtól eltérő cselekvés}

Szociológiai szemléletben az egyének gyermekvállalását alapvetően a társadalmi környezet szabja meg. Andorka Rudolf szavait idézve, fennáll egy „gyerekszám-norma”, amely mögött a társadalom tagjainak azon meggyőződése húzódik, hogy „az adott norma megtartása értékes viselkedést” jelent (1990 [1988]: 109, 111). E norma alapját képező érték tulajdonképpen azt a választást befolyásolja, ami során megtörténik a „,rendelkezésre álló módozatok, eszközök és a tevékenység céljai közötti” szelekció (Kluckhohn 1951, idézi: Lesthaeghe Moors 2000: 40). A szülők gyermekszámra vonatkozó döntésük során ezáltal olyan értékeket és normákat követnek, amelyeket társadalmi környezetükben általánosan elfogadnak. ${ }^{2}$

Egy társadalomban az ideálisnak tartott gyermekszám paramétere, amelynek mutatóját a demográfiai szakirodalom a társadalmi nyomás hatására kialakuló gyermekszám-elképzelés legjobb mérőszámának tekint (Blake 1966, 1968, idézi: S. Molnár 2010: 262), tükrözi az adott országban elterjedt szokásokat és hagyományokat (S. Molnár - Pongrácz 2002: 391). Napjainkban a magyar társadalom többsége a kétgyermekes családnagyságot tartja optimálisnak, e családmodell dominanciáját a tényleges termékenység mutatója is illusztrál (S. Molnár 2011: 72-73). E megállapításokból arra lehet következtetni, hogy a háromgyermekes családok alkotnak egy speciális csoportot a hazai társadalmon belül (Alich 2004: 7).

Felvetődik a kérdés, miért cselekednek a sokgyermekes családok az ideálisnak tartott gyermekszámtól eltérő módon?

A problémára a neves szociológus, Merton adhat részben magyarázatot. Az amerikai szakember elgondolását alapul véve, a három gyermek megléte az egyének sajátos társadalmi helyzetéből következik. A társadalomban ugyanis fennállnak a tagjai által jogosnak tartott célok, melyek elérését a társadalmi struktúra teszi lehetővé (Merton 1980 [1949]: 341, 386), míg „eszközeit minden esetben normák korlátozzák” (Merton 1980 [1949]: 342). Az egyes csoportok azonban eltérő eséllyel rendelkeznek a célkitűzések teljesítésére: a társadalom

\footnotetext{
${ }^{2}$ Szociológiai szempontból a weberi értékracionális cselekvés dominál a családok gyermekszámának eldöntésekor. A szülők az alapján mérlegelnek, hogy az általuk elfogadott értékek tekintetében hogyan járnak a „legértékesebben” (Andorka 1990 [1988]: 109), így a cselekvés értelme voltaképpen magában a tevékenységben rejlik. Az egyén „az elörelátható következményekre való tekintet nélkül azt teszi, amit a kötelesség, [...] a vallási elöírás [...] vagy bármiféle „ügy” fontossága parancsol neki” (Weber 1987 [1922]: 53-54). A szülők ebből adódóan nem azért vállalnak adott számú gyermeket, mert az elöreviszi öket más, relevánsabb céljaik elérésében, hanem azért döntenek három gyermek mellett, mert meggyőződésük alapján ezt találják kívánatosnak.
} 
alsó rétegeit lehetőségei korlátozzák törekvéseik megvalósításában, emiatt a „társadalmi struktúra legalján élők” között nagyobb az eltérő viselkedésmód különböző formáinak aránya (Merton 1980 [1949]: 365, 367).

Merton nézetét a termékenységre vonatkoztatva feltételezhető, hogy a családok rossz társadalmi pozíciójuk miatt vállalkoznak az ideálisnak tekintett szinttől nagyobb számú utódra. A magyar társadalomban leginkább preferált életcélok közé tartozik manapság a megfelelő jövedelem, a munkasiker, a biztonságnyújtás, a harmónia - a többségi társadalom állásfoglalása értelmében mindazonáltal a három gyermek vállalása nem egyeztethető össze e tervekkel (S. Molnár 2011: 85-86). Az alsó társadalmi csoportok kedvezőtlen helyzetük - például az alacsony jövedelem vagy a munkanélküliség - miatt nem tudják teljesíteni e terveket a normák által elvárt módon (például keresőtevékenység folytatásával). Az anyagi értékek iránti igény és azok megszerzésének reális lehetősége közötti szakadék egyre inkább növekszik a hátrányos pozíciójú rétegekben, így ezen csoportok „új” - a megszokottól eltérő - eszközöket alkalmaznak célkitűzéseik megvalósítása érdekében. A legszegényebb rétegekben egyre több gyermeket vállalnak a családok, akiktől a materiális célok beteljesülését várják, ezáltal a „stratégiai gyermekek” többsége rendszerint sokgyermekes családban jön világra (Gyenei 2008).

\section{Az értékrend szerepe}

Az általánosan elfogadott kétgyermekes családmodelltől eltérő harmadik gyermek vállalása részben a családok társadalomban és gazdaságban betöltött kedvezőtlen strukturális pozíciójából következik, amely nem teszi lehetővé jövőre irányuló terveik más módon történő megvalósítását. E tekintetben a harmadik gyermek világrajövetele az alsó társadalmi rétegek számára kis kockázattal járó alternatívát jelent, ezért feltételezhető, hogy például rossz foglalkozási, jövedelmi, illetve képzettségi helyzettel rendelkező anyák vállalkoznak inkább magasabb gyermekszámra.

Másrészt viszont nem szabad figyelmen kivül hagyni a beállítódások szerepét sem, így a harmadik gyermek mellett szóló döntés oka az egyének értékrendjében is keresendő. A hazai közfelfogásban jelen van egy nézet, miszerint a többgyermekes „családok általában gyermekszeretők, családcentrikusak” (S. Molnár - Pongrácz 2002 [1996]: 395). E szempont alapján, véleményem szerint, nem lehet egyértelműen arra következtetni, hogy a kétgyermekes normától eltérő viselkedés leginkább a társadalom alsó rétegeit érintené. A gyermek- 
centrikus attitüd összefüggésbe hozható ugyanis a vallásosabb, tradicionálisabb értékeket valló magatartással (S. Molnár - Kapitány 2002: 65), amely esetében - a szocialista időszakkal szemben - ma már nem lehet kijelenteni, hogy csak a hátrányos társadalmi háttérrel rendelkező csoportokat ${ }^{3}$ jellemezné a vallásos gondolkodásmód (Rosta 2011: 747). A gyermekközpontú beállítódás azonban kapcsolatban áll az alacsonyabb iskolai végzettséggel is (S. Molnár Kapitány 2002: 65), ezért a kedvezőtlen státuszú rétegek felülreprezentált helyzete sem zárható ki a családorientált viselkedés tekintetében.

Az értékbeállítódások szerepére utaló feltételezéseim az alábbiak:

H4: A vallásosság fokának emelkedése pozitív módon járul hozzá a harmadik utód megszületésének elképzeléséhez.

H5: Azon anyák körében, akik egyetértenek azzal az állítással, miszerint a gyermekek számának növekedése fontosabb, mint a munka, magasabb a harmadik gyermek-vállalás intenciójának valószínűsége, mint a kevésbé gyermekcentrikus nézeteket valló személyek esetében.

\section{További demográfiai tényezők hatása}

A harmadik gyermek megszületésének szándékára irányuló, fentiekben ismertetett előzetes felvetéseimet az intenciót befolyásoló három faktor operacionalizálásával elméleti következtetésekre alapozva alakítottam ki. Öszszefoglalva, nézetem szerint a családok gyermekszámának alakulása függ az egyének objektív (strukturális) helyzetétől, másrészt kapcsolatban áll az általuk elfogadott értékekkel, beállitódásokkal, továbbá a gondolkodásmódjukból küIön kiemelt jövőre irányuló perspektíváikkal (szubjektív pozíció). Másodsorban hipotéziseim kidolgozásánál figyelembe vettem a témával foglalkozó felmérések tapasztalatait. A korábbi kutatási eredmények szerint a kétgyermekes anyák demográfiai jellemvonásai és lakókörülményei is hatást gyakorolnak a termékenységi viselkedésre. Ezen elemzések összegző megállapításai, valamint az észrevételek alapján kidolgozott hipotéziseim a következők:

A harmadik gyermek világrajövetelének szándéka negatív viszonyban áll az anya életkorának növekedésével. A 25-29 éves nők nagyobb eséllyel szeretnének meglévő gyermekeik mellé újabb utódot vállalni életük folyamán, mint a

\footnotetext{
${ }^{3}$ Ráadásul a fiatalabb, hívő generáció körében a magasabb státuszú rétegek enyhe túlsúlya figyelhető meg (Hegedüs 2007, idézi: Rosta 2011: 747).
} 
30 évesnél idősebb korcsoportba tartozó anyák. Az életkor előrehaladása tehát csökkenti a harmadik gyermek intenciójának valószínűségét (Miettinen - Basten - Rotkirch 2011: 495).

H8: Minél fiatalabb az anya, annál valószínủbb az újabb utód világrahozatalának szándéka.

Általános megállapításként deklarálható a felmérések értelmében, hogy a szülővé válás későbbi időpontja kedvezőtlen irányban hat a harmadik gyermek világrajövetelének esélyére. Minél idősebb korban szüli meg első gyermekét a nő, annál kisebb valószínűséggel tölti be harmadszor is anyaszerepét (Alich 2004: 119, Statistics Sweden 2011: 55, Yavuz 2006: 447).

H9: A nők mielőbbi szülővé válása elősegíti a családbővités tervét.

Az anya testvéreinek száma egyértelmü kapcsolatot mutat az újabb családbővités kockázatával. Minél több testvére van a személynek, annál nagyobb a harmadik gyermek világrahozatalára vonatkozó kedvező szándék esélye (Miettinen - Basten - Rotkirch 2011: 495).

H10: Minél több testvérrel rendelkezik az egyén, annál inkább szeretne harmadik gyermeknek életet adni.

Amennyiben az első és a második gyermek neme azonos, magasabb eséllyel vállalkozik az anya harmadik gyermekre, mint ellenkező nemű utódok esetében (Alich 2004: 118).

H11: Az azonos nemű gyermekek pozitív módon járulnak hozzá a harmadik utód megszületésének szándékához, míg az ellentétes nemü testvérek gyengítik ennek esélyét.

Negatív kapcsolat érvényesül a meglévő gyermekek életkora közötti kü-lönbség és a harmadik utód vállalásának kockázata között, ezért az első és a második gyermek közti nagyobb időtáv csökkenti az újabb testvér érkezésének esélyét (Hoem - Hoem 1989, idézi: Alich 2004: 84, Kravdal 1990: 60). A szülések közötti intervallum ugyanis a magasabb paritásoknál egyre inkább visszaesik, így legnagyobb valószínűséggel akkor adnak életet ismét gyermeknek a két-gyermekes anyák, ha az első és második utód közötti korkülönbség csekély (Berinde 1999, idézi: Alich 2004: 85, Hoem - Prskawetz - Neyer 2001: 31, 46).

H12: Minél kisebb a meglévő gyermekek életkora közötti különbség, annál magasabb az ismételt gyermekvállalás valószínúsége. 
A kétgyermekes személyek családi állapotát tanulmányozva nem áll fenn differencia a házasságban és az élettársi kapcsolatban élő nők harmadik utód vállalásának esélye között. A partnerrel rendelkező anyák ugyanakkor magasabb valószínűséggel adnak életet ismét gyermeknek, mint az egyedülálló egyének (Statistics Sweden 2011: 56).

H14: A partnerével együtt élő (házas vagy élettársi kapcsolatban lévő) anya nagyobb eséllyel kiván harmadszor is gyermeket szülni, mint a kapcsolatban lévő, de párjával nem egy háztartásban élő vagy egyedülálló nő.

A vidéken élő kétgyermekes nők nagyobb eséllyel vállalják harmadik gyermeküket, mint a városi lakóhellyel rendelkező egyének (Kravdal 1990: 82). Számottevően befolyásolja a gyermekszám gyarapodását a szülők lakáskörülménye is. A kertes házban élő egyének magasabb eséllyel hozzák világra harmadik gyermeküket, mint a társasházban lakó anyák (Westoff - Potter - Sagi 1963, idézi: Andorka 1987: 137).

H15: A községben vagy városi családi házban élő nő magasabb valószínűséggel szándékozik harmadik gyermeknek életet adni, mint a városi jogállású településen, nem családi házban lakó egyén.

\section{A HARMADIK GYERMEKRE VONATKOZÓ INTENCIÓ EMPIRIKUS ELEMZÉSE}

Napjainkra nyilvánvalóvá vált, hogy a termékenységi választásokat komplex folyamatként kell kezelni (Rosina - Testa 2009: 490), ezáltal az utóbbi évtizedekben egyre növekvő hangsúlyt kapott az a felfogás, amely a gyermekvállalási döntésekben az egyén értékei, strukturális helyzete mellett kulcsszerepet tulajdonít a szándékok megfogalmazódásának is.

A szándékolt és a tényleges termékenység közötti kapcsolat azonban nem ellentmondásoktól mentes. Ahogy Magyarországon, úgy a többi fejlett államban is magasabb gyermekszám-értékben fogalmazzák meg terveiket a nők, mint a valós termékenység mértéke (Philipov - Testa 2008). Ezen eltérés okát Bongaarts (1998: 20-26) három tényezőben látta: a gyermekszülés magasabb életkorra történő időzítése (1.), az akaratlan meddőség jelensége (2.), valamint a gyermekvállalásnál fontosabbnak itélt faktorok (gazdasági, társadalmi, egészségügyi helyzet) (3.) egyaránt csökkentik a tényleges gyermekszámot a kívánt paraméterhez viszonyítva. Spéder Zsolt és Kapitány Balázs (2014) négy ország (Hollandia, Svájc, Magyarország, Bulgária) adatait tanulmányozó, 
nemzetközi összehasonlító vizsgálata szintén arra hívja fel a figyelmet, hogy az egyének társadalmi és demográfiai helyzetei megnehezíthetik a tervezett gyermekek világrajövetelét. Az idősebb életkor, a gyermektelenség, a két vagy több gyermek megléte, illetve a párkapcsolat megszakadása egyértelműen kedvezőtlen eredményt - halasztást vagy végleges lemondást - fejt ki az időzített szándék sikeres megvalósítására (2014: 167-171).

A szándékolt és a valós termékenység között fennálló eltérés és a tervek lehetséges realizálatlansága okán az intenció nem tekinthető döntő jelentőségű változónak a gyermekszám magyarázatában (Philipov - Testa 2008: 3). A preferenciák, a vágyak, valamint a szándékok alakulása - a rá ható tényezők által, amelyek a magatartást is befolyásolják - ugyanakkor információval szolgálhatnak a tényleges termékenységi viselkedésről (van de Kaa 1998: 36-38). A szándék voltaképpen, mint egy kulcs jelenik meg a közeli gyermekvállalási magatartás előrejelzésében (Schoen és munkatársai 1999, idézi: Testa 2010: 19), így nélkülözhetetlen szerepe a majdani valós cselekvés jövőbeni bekövetkezésében rejlik.

A gyermekvállalási intenció és a viselkedés kapcsolatát tárgyaló kutatások jelentős része az Ajzen-féle szociálpszichológiai megközelítést veszi alapul. A szándékolt cselekvés elmélete az intenció közvetlen hatását hangsúlyozza a cselekvés és a kitűzött cél megvalósításában (Ajzen 1991: 182), ebből kifolyólag a termékenységi cselekvésre vonatkozó gondolatmenetemet a hivatkozott elképzelés felhasználásával dolgoztam ki (1. ábra).

1. ábra: A gyermekvállalási cselekvés modellje, az Ajzen-modell átdolgozott változata The model of childbirth action, a modified version of the Ajzen-modell

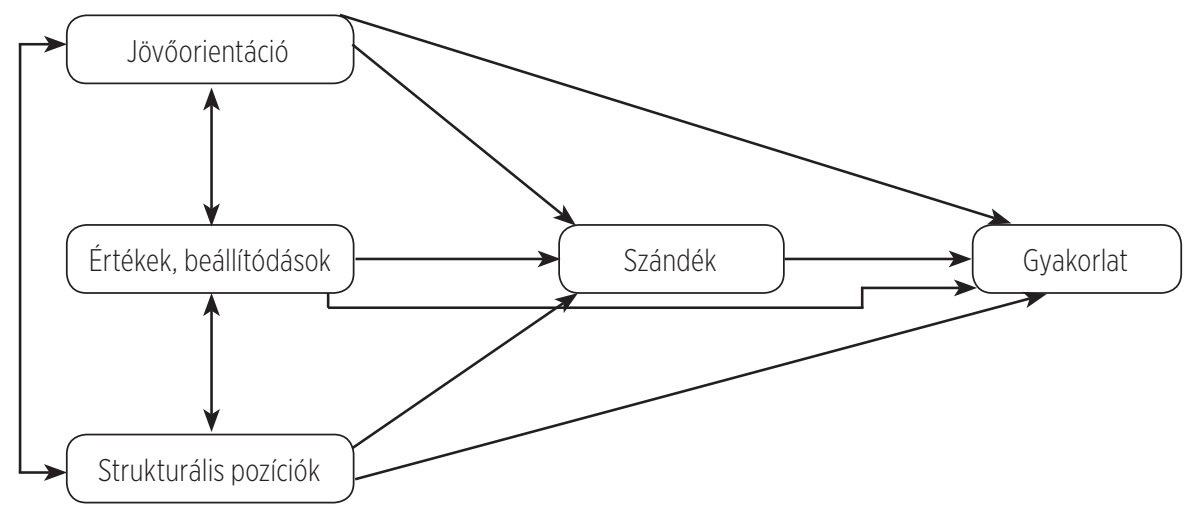


A harmadik gyermek vállalásának elméleti keretét szemléltető fejezetekben részletezett meggyőződésem értelmében, a gyermekszámra irányuló elhatározás folyamán az egyének számításba veszik értékorientációjukat, a beállítódásaikból külön kiemelt jövőre irányuló perspektívájukat, illetve strukturális pozícióikat. Ezen - egymástól nem független - elemek egyaránt hatást fejtenek ki a jövőbeli termékenység szándékára.

A gyermekvállalás mint komplex cselekvési gyakorlat a tényezők együttes hatásának eredményeként realizálódik. A tényleges termékenységben megnyilvánul az egyén jövőorientációjának (1.), gyermekvállalással kapcsolatos beállítódásainak, attitüdjeinek (2.), strukturális helyzetének szerepe (3.), továbbá tükröződik az előbbi három dimenzió által befolyásolt intenciók funkciója is (4.).

A felvázolt összefüggések alapján a harmadik gyermek vállalásának folyamata két lépésre bontható: elsőként az egyének objektív és szubjektív jellemzői a harmadik utód világrajövetelére vonatkozó szándékot magyarázzák, majd másodízben együttesen határozzák meg a harmadik gyermek megszületésére irányuló cselekedetet.

Ezen összetett viszony miatt először a harmadik gyermek vállalásának intencióját kell megvizsgálni ahhoz, hogy később választ kapjunk arra a kérdésre, miért ad kevés magyar anya életet harmadik számú utódnak? Tanulmányomban így annak elemzésére helyeztem a hangsúlyt, hogy a két gyermeket nevelő nők mely jellemvonásai befolyásolják a harmadik gyermek világrahozatalának szándékát: Milyen módon hatnak a személyek strukturális pozíciói (1.), értékei (2.), valamint jövőirányultságára utaló nézetei (3.) arra, hogy kívánnak-e az egyének harmadik utódot?

Kutatásom során a KSH Népességtudományi Kutatóintézet által készitett Életünk fordulópontjai adatfelvétel első hullámának adatbázisát használtam fel. Vizsgálati kérdésem arra irányult, hogy kik azok a két gyermeket nevelő anyák, akik szeretnének életük folyamán harmadszor is szülővé válni. A válaszadó nők 83,3\%-a nem kiván, míg 16,7\%-a egyértelmüen szándékozik harmadik gyermeket világra hozni (2. ábra).

A gyermekvállalási cselekvés intencióját - a korábbiakban felvázolt módon - több paraméter által meghatározott folyamatként értelmeztem, amelyben a gyermek megszületésére irányuló szándékot jövőorientációk, értékrendek és a személyek objektív helyzetei irányítják. Felmérésemben arra kerestem a választ logisztikus regressziós módszerrel, hogy a két gyermeket nevelő anyák strukturális pozíciói, attitüdjei, valamint jövőre irányuló beállítottságai milyen hatást fejtenek ki az egyének harmadik gyermek vállalására vonatkozó általában vett intenciójára. 
2. ábra: Szeretne-e további gyermeknek életet adni?

Would you like to have another child?

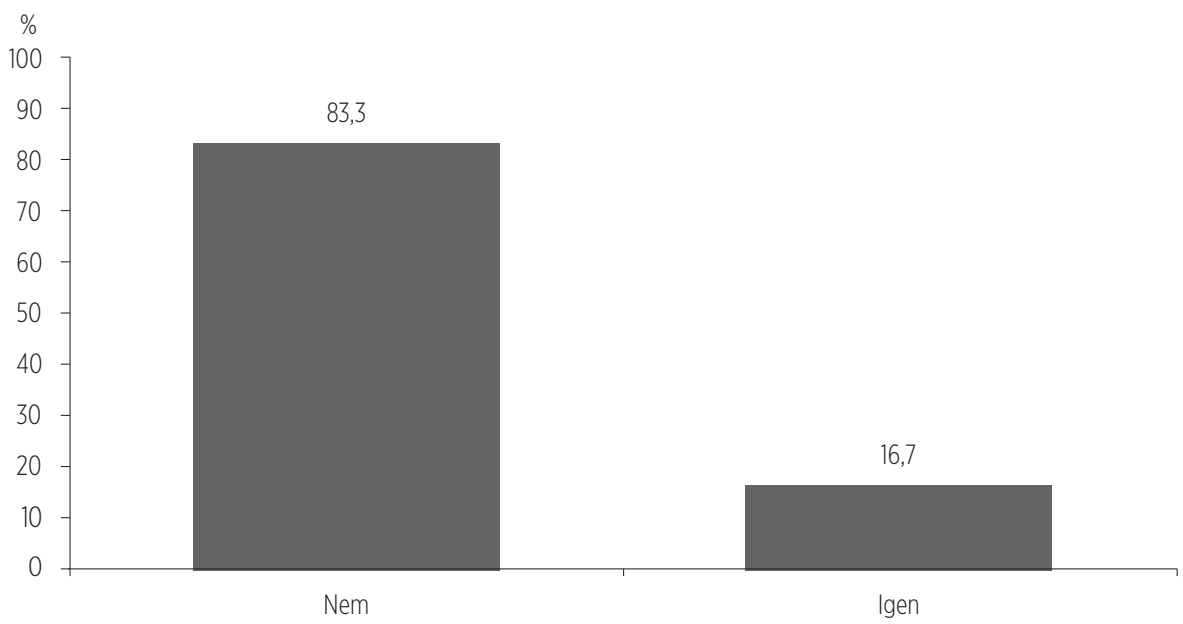

Forrás: KSH NKI, Életünk fordulópontjai adatfelvétel 1. kérdezési hullám. Saját számítás.

\section{Módszertan}

Logisztikus regressziós elemzésemet azon szülőképes korú (45 éves vagy fiatalabb) anyák körében végeztem el, akik a 2001. évi adatfelvétel idején két saját gyermeket neveltek a háztartásukban, és esélyük volt újabb gyermeknek életet adni (n=1097). A gyermekszám kialakításakor nem vettem figyelembe azokat a saját gyermekeket, akik nem az anya háztartásában éltek, továbbá a háztartásban nevelt nem saját utódokat sem. A mintába nem kerültek bevonásra mindemellett azok az anyák, akik a 2001. évi adatfelvétel során második vagy harmadik gyermeküket várták, illetve azon személyek, akik úgy nyilatkoztak, hogy nem lehet több gyermekük.

Elemzésemben a logisztikus regressziós modell függő változóját az általam létrehozott „harmadik gyermek vállalásának szándéka” paraméter képezte. A modell magyarázó változóit az 1. táblázat tartalmazza.

A kutatásom szempontjából lényeges változók egy része megfelelő formában állt rendelkezésemre az adatállományban, számos mutatót azonban átalakítottam. A változók végleges kategóriáit és az anyák elemszámának magyarázó paraméterek szerinti alakulását a 2. táblázat tartalmazza. 
1. táblázat: A harmadik gyermek-vállalás szándék logisztikus regressziós modelljének magyarázó változói

The explanatory variables in the logistic regression model of the intention of giving birth to the third child

Független változók

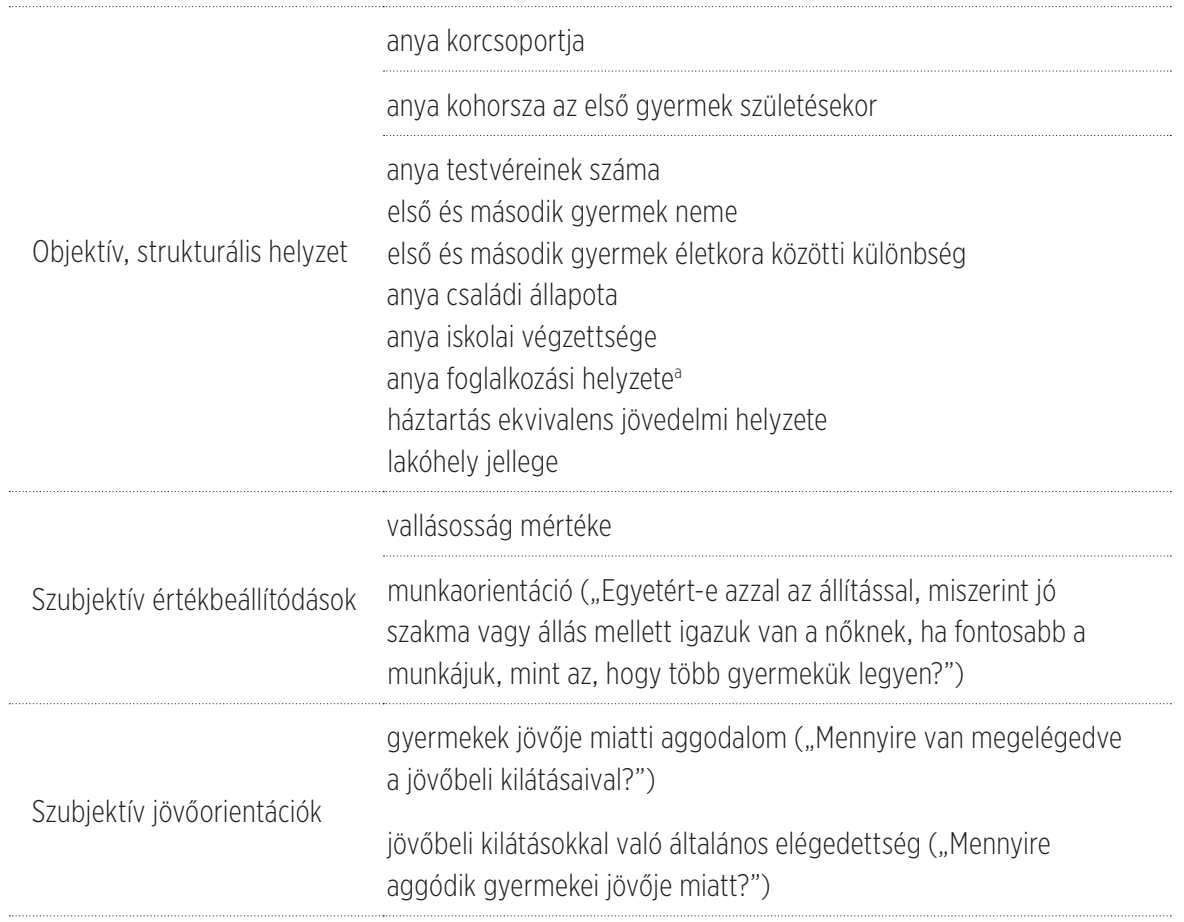

a A foglalkozási helyzet magyarázó változója esetében foglalkoztatottként jelöltem azon személyeket, akik keresőtevékenységet végeztek, a nem foglalkoztatott kategóriába soroltam a munkanélküli, a háztartásbeli vagy a tanulói státusszal bíró anyákat, továbbá külön csoportként definiáltam az adatfelvétel idején is anyasági ellátáson lévő nőket.

\section{A modellezés logikája}

Első lépésként kétváltozós összefüggések vizsgálatára került sor, az elemzések eredményeinek részletes bemutatásától e tanulmányban eltekintek. A független változók tisztítatlan hatásainak elemzése után először az anyák objektív, strukturális helyzetének paramétereit - előbb a demográfiai, majd a társadalmi, gazdasági, a lakókörülmények pozícióit - illesztettem a modellbe. Külön regressziót készítettem ezután a nők értékbeállítódásaira utaló, továbbá 
jövőirányultságára vonatkozó változók esetében is. Végül az összes előzőekben külön vizsgált változó beléptetésével eljutottam a teljes modellig. A logisztikus regressziós modell eredményeit a 3. táblázat tartalmazza.

2. táblázat: A két gyermeket nevelő anyák és a közülük harmadik gyermeket vállalni szándékozó nők száma a magyarázó változók kategóriái szerint

The number of mothers with two children and the number of women among then intending to give birth to their third child by the categories of explanatory variables

\begin{tabular}{|c|c|c|c|}
\hline Magyarázó változó & & $\begin{array}{l}\text { Az anyák száma a } \\
\text { magyarázó változók } \\
\text { szerint, fő }\end{array}$ & $\begin{array}{c}\text { A harmadik gyermeket } \\
\text { vállalni szándékozók } \\
\text { száma, fő }\end{array}$ \\
\hline \multirow[t]{5}{*}{ Anya korcsoportja } & 20-24 év & 29 & 12 \\
\hline & 25-29 év & 139 & 51 \\
\hline & 30-34 év & 234 & 48 \\
\hline & 35-39 év & 265 & 44 \\
\hline & 40-45 év & 325 & 11 \\
\hline \multirow{3}{*}{$\begin{array}{l}\text { Anya korcsoportja az } \\
\text { első } \\
\text { gyermek vállalásakor }\end{array}$} & 15-19 év & 169 & 30 \\
\hline & 20-24 év & 625 & 94 \\
\hline & 25 év vagy felette & 198 & 42 \\
\hline \multirow{5}{*}{$\begin{array}{l}\text { Anya testvéreinek } \\
\text { száma }\end{array}$} & 0 & 123 & 20 \\
\hline & 1 & 447 & 79 \\
\hline & 2 & 236 & 42 \\
\hline & 3 & 80 & 8 \\
\hline & 4 vagy több & 104 & 17 \\
\hline \multirow{3}{*}{$\begin{array}{l}\text { Első és második } \\
\text { gyermek neme }\end{array}$} & azonos (fiú) & 277 & 57 \\
\hline & azonos (lány) & 223 & 37 \\
\hline & ellentétes & 489 & 72 \\
\hline \multirow{3}{*}{$\begin{array}{l}\text { Első és második } \\
\text { gyermek } \\
\text { korkülönbsége }\end{array}$} & 0-2 év & 285 & 55 \\
\hline & 3-6 év & 560 & 99 \\
\hline & 7 év vagy több & 147 & 12 \\
\hline \multirow[t]{4}{*}{ Anya családi állapota } & házas & 819 & 135 \\
\hline & élettársa van & 61 & 16 \\
\hline & $\begin{array}{l}\text { partnere van, de nem } \\
\text { élnek együtt }\end{array}$ & 19 & 6 \\
\hline & egyedülálló & 93 & 9 \\
\hline \multirow{3}{*}{$\begin{array}{l}\text { Anya foglalkozási } \\
\text { helyzete }\end{array}$} & foglalkoztatott & 684 & 92 \\
\hline & nem foglalkoztatott & 143 & 19 \\
\hline & anyasági ellátáson van & 165 & 55 \\
\hline \multirow[t]{4}{*}{$\begin{array}{l}\text { Anya iskolai } \\
\text { végzettsége }\end{array}$} & $\begin{array}{l}8 \text { osztály vagy } \\
\text { alacsonyabb }\end{array}$ & 176 & 27 \\
\hline & szakmunkásképző & 266 & 34 \\
\hline & érettségi & 362 & 64 \\
\hline & felsőfok & 188 & 41 \\
\hline
\end{tabular}

Forrás: KSH NKI, Életünk fordulópontjai adatfelvétel 1. kérdezési hullám. Saját számítás. 
2. táblázat: A két gyermeket nevelő anyák és a közülük harmadik gyermeket vállalni szándékozó nők száma a magyarázó változók kategóriái szerint (folytatás)

The number of mothers with two children and the number of women among then intending to give birth to their third child by the categories of explanatory varia (continued)

\begin{tabular}{|c|c|c|c|}
\hline Magyarázó változó & & $\begin{array}{l}\text { Az anyák száma a } \\
\text { magyarázó változók } \\
\text { szerint, fő }\end{array}$ & $\begin{array}{c}\text { A harmadik gyermeket } \\
\text { vállalni szándékozók } \\
\text { száma, fő }\end{array}$ \\
\hline \multirow{5}{*}{$\begin{array}{l}\text { Háztartása ekvivalens } \\
\text { jövedelmi helyzete }\end{array}$} & legalacsonyabb ötöd & 284 & 39 \\
\hline & második ötöd & 152 & 25 \\
\hline & harmadik ötöd & 150 & 21 \\
\hline & negyedik ötöd & 190 & 38 \\
\hline & legmagasabb ötöd & 135 & 29 \\
\hline \multirow[t]{7}{*}{ Lakóhely jellege } & $\begin{array}{l}\text { Budapest } \\
\text { (családi ház) }\end{array}$ & 36 & 6 \\
\hline & $\begin{array}{l}\text { Budapest } \\
\text { (nem családi ház) }\end{array}$ & 57 & 19 \\
\hline & $\begin{array}{l}\text { megyei jogú város } \\
\text { (családi ház) }\end{array}$ & 71 & 16 \\
\hline & $\begin{array}{l}\text { megyei jogú város } \\
\text { (nem családi ház) }\end{array}$ & 133 & 31 \\
\hline & $\begin{array}{l}\text { egyéb város } \\
\text { (családi ház) }\end{array}$ & 197 & 20 \\
\hline & $\begin{array}{l}\text { egyéb város } \\
\text { (nem családi ház) }\end{array}$ & 98 & 12 \\
\hline & község & 400 & 62 \\
\hline \multirow[t]{4}{*}{ Anya vallásossága } & $\begin{array}{c}\text { vallásos, az egyház } \\
\text { tanításait követi }\end{array}$ & 127 & 34 \\
\hline & maga módján vallásos & 587 & 86 \\
\hline & $\begin{array}{l}\text { nem tudja } \\
\text { megmondani, hogy } \\
\text { vallásos-e }\end{array}$ & 38 & 5 \\
\hline & nem vallásos & 232 & 41 \\
\hline \multirow[t]{3}{*}{ Munkaorientáció } & $\begin{array}{l}\text { nem ért egyet azzal, } \\
\text { hogy fontosabb a } \\
\text { munka, mint a több } \\
\text { gyermek }\end{array}$ & 611 & 125 \\
\hline & bizonytalan & 122 & 16 \\
\hline & egyetért & 252 & 25 \\
\hline \multirow[t]{3}{*}{$\begin{array}{l}\text { Gyerekek jövője miatti } \\
\text { aggodalom }\end{array}$} & $\begin{array}{l}\text { egyáltalán nem } \\
\text { aggódik }\end{array}$ & 32 & 10 \\
\hline & kicsit aggódik & 269 & 56 \\
\hline & nagyon aggódik & 690 & 99 \\
\hline \multirow[t]{3}{*}{ Általános jövőkép } & pesszimista & 61 & 11 \\
\hline & semleges & 284 & 39 \\
\hline & optimista & 647 & 116 \\
\hline
\end{tabular}

Forrás: KSH NKI, Életünk fordulópontjai adatfelvétel 1. kérdezési hullám. Saját számítás. 


\section{Eredmények}

\section{Tisztítatlan hatások}

A magyarázó változók tisztítatlan hatásainak vizsgálata rávilágított arra, hogy önmagában az anya szülővé válásának életkora, testvéreinek száma, illetve általános jövőképe nem áll érdemi összefüggésben a harmadik gyermek megszületésére irányuló szándék esélyével, számos paraméter ugyanakkor szignifikánsan befolyásolja az újabb családbővités intenciójának kockázatát.

Az anya életkorát vizsgálva legmagasabb valószínüséggel a referenciakategóriaként megjelölt 20-24 éves korosztály kiván harmadik utódnak életet adni, de érdemileg nem különbözik a 25-29 éves nők esélye sem. A 30 évesnél idősebb anyák körében viszont folyamatosan visszaesik a kockázat: a 30-39 éves kohorsz kb. harmadannyi, míg a 40 év felettiek huszadannyi valószinűséggel tervezik harmadik gyermekük világrahozatalát, mint a legfiatalabb korosztály.

Számottevő hatás mutatható ki az anya meglévő gyermekeinek nemét és korkülönbségét tanulmányozva is. Másfélszer nagyobb eséllyel szándékozik harmadik gyermeket szülni az a kétgyermekes szülö, akinek gyermekei azonos neműek, mint az a nő, aki egyaránt nevel fiú és lány utódot is. Az első és második gyermekének legfeljebb kétéves eltéréssel életet adó anyák háromszor magasabb kockázattal kívánják harmadszor is betölteni szülőszerepüket, mint azok a személyek, akik utódaik között 7 vagy annál több év korkülönbség áll fenn.

A kétgyermekes anyák családi állapota - az előbbi mutatókhoz hasonlóan tisztítatlan formában szignifikánsan határozza meg a harmadik gyermek világrajövetelének intencióját. A partnerükkel nem együtt élő nők több mint kétszer több, az élettársi kapcsolattal rendelkező anyák mintegy másfélszer nagyobb, míg az egyedülálló személyek feleannyival kisebb valószínúséggel vágynak harmadik gyermeknek életet adni, mint a házas egyének.

Az anyák iskolai végzettsége önmagában csak nagyon csekély hatást fejt ki a harmadik gyermekvállalás szándékára, így az iskolázottsági kategóriák között nem áll fenn érdemi különbség az intenció tekintetében.

Az anya foglalkozási pozícióját szemügyre véve kitűnik, hogy csupán az anyasági ellátáson lévő nők esélye különbözik lényegesen a nem foglalkoztatott anyák kockázatától. Az előbbi státuszú egyének háromszor akkora valószínűséggel szeretnének harmadszor is szülővé válni, mint a nem foglalkoztatottként definiált anyák.

Az ekvivalens jövedelmi helyzet tisztítatlan hatása nem a várt irányba mutat. Bár mindössze a két legkedvezőbb jövedelmi ötöd esélye tér el érdemileg 
a legrosszabb jövedelmi pozíciójú háztartás kockázatától, a legmagasabb ötödökbe sorolt háztartásokban élő anyák másfélszer nagyobb valószínűséggel szándékoznak harmadik gyermeket vállalni.

Az anya lakóhelyének jellege önmagában ugyancsak szignifikánsan magyarázza a gyermekszám bővítés irányába ható intenciót. A referenciaként megjelölt, községben élő személyekhez viszonyítva Budapesten, illetve megyei jogú településen, nem családi házban élő két gyermeket nevelő nők számottevően nagyobb eséllyel kívánnak harmadik utódot világra hozni, míg az egyéb városi, kertes ingatlannal rendelkező egyének a falusiaknál kisebb kockázattal vágynak a harmadszori gyermekáldásra.

Az anyák vallásossága és munkaorientációja tekintetében a feltételezett módon nyilvánul meg a változók befolyása. Az egyház tanításait követő nők kétszer magasabb kockázattal szeretnének harmadik gyermeket szülni, mint a kevésbé vallásos vagy egyáltalán nem hívő személyek. A munkájukat nem gyermekszámuk növelése elé helyező anyák szintén kb. kétszer akkora eséllyel szándékoznak harmadszor is szülővé válni, mint a bizonytalan nézetű, vagy a munkájuk iránt erősen elköteleződött egyének.

A kétgyermekes anyák jövőorientációjára utaló paraméterek közül önmagában csak a gyermekek jövője miatti aggodalom indexe fejt ki szignifikáns hatást a harmadik gyermek intenciójára. E faktor esetében a csekély, illetve a közepes mértékű félelemmel rendelkező nők kockázata között nincs különbség, a szorongó anyák azonban harmadannyi valószínűséggel kívánnak újabb utódnak életet adni, mint az e tekintetben nem gondterhelt személyek.

\section{Demográfiai modell}

A kétgyermekes nők demográfiai státuszát meghatározó mutatók együttes beillesztése annak ellenére indukált központi változásokat, hogy az anyák testvéreinek száma továbbra sem jelez szignifikanciát, míg az életkor és a meglévő gyermekek neme tekintetében alapvetően nem módosultak a tisztítatlan hatások.

Az anyák családi állapota és gyermekeik korkülönbsége már nem magyarázza érdemben a harmadik gyermek vállalásának szándékát. Ezen utóbbi fordulatra a személyek anyává válási életkorának modellbe történő építése adhat választ: a paraméter önmagában nem határozta meg szignifikáns módon az intenció valószínűségét, más demográfiai indexek hatására viszont elvonta a gyermekek közti korkülönbség faktorának függő változóra kifejtett lényegi befolyását. 
Az első gyermeküknek 25 éves vagy annál idősebb korban életet adó nők ezáltal közel két és félszer nagyobb kockázattal szeretnének harmadik utódot szülni, mint a 20 éves életkoruk előtt anyává vált személyek.

\section{Strukturális modell}

A nők társadalmi, gazdasági, valamint lakókörülményeinek pozíciójára utaló mutatók logisztikus regressziós modellbe történő együttes bevonásával rendkivül mérséklődött e változók hatása.

Mindössze az anya foglalkoztatotti pozíciója őrizte meg némileg erős szignifikanciáját, viszont továbbra is csak az anyasági ellátáson lévő személyek esélye mutat érdemi különbséget a nem foglalkoztatott nők kockázatához képest (előbbi csoport harmadik gyermek vállalási szándékának valószínűsége elhanyagolható mértékben csökkent a kontrollfaktorok befolyásának eredményeként).

Megszünt az ekvivalens jövedelmi helyzet, valamint gyengült az anya lakóhelyének hatása. A községi jogállású településen élő személyek kockázata nem változott hangsúlyosan a megyei jogú városi, nem családi házban és egyéb, városi kertes épületben lakó egyének valószínűségéhez képest, ugyanakkor többé-kevésbé javult a budapesti, nem családi házban élő anyák esélyéhez viszonyítva (utóbbi csoportba tartozó nők háromszor nagyobb tisztítatlan kockázata alig kétszer nagyobb valószínüségre esett vissza).

Más strukturális faktorok beillesztése által ugyanakkor módosult az iskolai végzettség változójának hatása, kismértékű különbség realizálódik a legalacsonyabb és a legmagasabb iskolázottságú csoportok esetében. A felsőfokú végzettséggel rendelkező anyák közel kétszer nagyobb eséllyel szeretnének harmadik gyermeket vállalni, mint a 8 osztállyal vagy annál alacsonyabb iskolai végzettséggel rendelkező nők - jóllehet ezen megállapítás előzetes feltevésemmel ellentétes.

\section{Értékbeállítódás modell}

A két gyermeket nevelő anyák vallásosságának és munkaorientációjának egyszerre történő bevonása nem idézett elő mélyreható átalakulásokat a két változó hatásában.

Kismértékben csökkent mind az egyház tanításait követő, mind a munka iránti gyenge elkötelezettségü személyeknél a harmadszori gyermekvállalás- 
szándék esélyének előnye, de még mindig e két jellemvonású nők szeretnének a legmagasabb kockázattal ismét utódot világra hozni.

Érdemi változásként annyi jegyezhető meg, hogy a munkaorientáció kontrolljának következtében a bizonytalan vallási attitűddel rendelkező egyének elvesztették szignifikáns hatásukat, ezért azon anyák valószínűsége, akik nem tudják eldönteni, hogy vallásosak-e vagy sem, nem különbözik a hívő egyének harmadik gyermekre vonatkozó intenciójának kockázatától.

\section{Jövőorientáció modell}

A nők jövőorientációját kifejező változók modellbe történő együttes beillesztése után sem magyarázza érdemi módon az anyák általános jövőképe a harmadik utód megszületésére irányuló szándék esélyét.

A gyermekek jövője miatti aggodalom némiképp mérséklődött a nagyon gondterhelt egyének hátrányában, ugyanakkor ezt a javulást nem lehet meghatározónak tekinteni, így továbbra is a kevésbé aggodalmaskodó két gyermeket nevelő nők kívánnak magasabb kockázattal újabb utódnak életet adni.

\section{A teljes modell}

Az összes magyarázó változó együttes beemelését követően - amely a magyarázó erőt végül 31,4\%-ra növelte - megvalósult a teljes modell kiépítése. A harmadik gyermekvállalás szándékának logisztikus regressziós modellje rávilágítottarra, hogy a magyarázó változók együttes bevonása nagymértékben átformálta a mutatók által kifejtett tisztítatlan mechanizmusokat.

A két gyermeket nevelő anyák demográfiai státuszát jellemző paraméterek közül csupán a nők életkora és gyermekeinek neme befolyásolja érdemben a harmadszori szülővé válás szándékát. E két változó esetében beigazolódott előzetes feltevésem: minél idősebb az anya, annál kisebb eséllyel kíván harmadik utódot világra hozni (bár ezen összefüggés csak a 30 évesnél idősebb korosztályok körében állja meg a helyét), amelyhez pozitív módon járul hozzá a meglévő gyermekek azonos neme is. Ugyanakkor a családbővítés intenciójának kockázata nem függ a nők testvéreinek számától, anyává válásának életkorától (a mutatók önmagukban sem befolyásolták a függő változót), illetve családi állapotától és gyermekeinek korkülönbségétől (más strukturális faktorok kontrollálása által vesztették el hatásukat). 
A kétgyermekes nők társadalmi, gazdasági, valamint lakókörülményeinek pozíciójára utaló paraméterek esetében mindössze a személyek lakóhelyének jellege magyarázza szignifikánsan a harmadik utód megszületésének intencióját. E mutatót figyelembe véve hipotézisemmel ellentétes következtetésre jutottam: meglepő módon a budapesti vagy megyei jogú városi, nem családi házban élő személyek magasabb eséllyel szeretnének harmadik gyermeket szülni, mint a községi lakosok - ezen összefüggés meglétére azonban nem találtam megfelelő szociológiai magyarázatot, így az eredmény megértése további kutatást igényel. Az ekvivalens jövedelmi helyzet és az iskolai végzettség mutatója éppen más strukturális faktorok, míg a foglalkozási pozíció a demográfiai sajátosságokat, illetve az értékorientációkat jelző tényezők befolyása miatt vesztette el szignifikanciáját. Mindezek következtében utóbbi paraméterekre vonatkozó elképzeléseim is megcáfolódtak.

Többé-kevésbé igazolást nyertek viszont az egyének értékrendjeire felállított feltételezéseim. Minél inkább egyetért az anya azzal az állitással, miszerint a munka fontosabb, mint a gyermekek számának növelése, annál kisebb a harmadik gyermeket szülni tervezők szándékának kockázata. A munkaorientációval ellentétben ugyanakkor a vallásosság mértékével nem párhuzamosan csökken a harmadikutódra irányuló intenció valószínűsége. Jóllehet a maga módján vallásos vagy nem hívő nők jóval kisebb eséllyel szeretnének ismét gyermeknek életet adni, mint az erősen vallásos anyák, várakozásommal (miszerint legkevésbé a nem vallásos anyák vágynak leginkább harmadik gyermekre) szemben azonban a bizonytalan beállítottságú személyek szeretnének a legkevesebb kockázattal ismét szülni - így ez irányú hipotézisem csak részben igazolódott be.

Az értékrendekkel ellentétben az egyének jövőorientációja nem fejt ki szignifikáns hatást a nők harmadszori anyává válásának szándékára, ezért egyik változó sem támasztja alá kiinduló feltevéseimet. A személyek általános jövőképe nemcsak a végső modellben, hanem tisztítatlan formában sem befolyásolja számottevően a családbővités intencióját, míg a gyermekek jövője miatti aggodalom hatása az objektív mutatók és az értékindexek által kontrollálva szünik meg.

Összességében véve az anyák életkora, gyermekeinek neme, lakóhelyének jellege, vallásossága, illetve munkaorientációja magyarázza érdemi módon a harmadik gyermek vállalásának szándékát. Legnagyobb eséllyel a 30 év alatti, azonos nemű gyermekeket nevelő, a munka iránt kevésbé elkötelezett, budapesti vagy megyei jogú városi, nem családi házban élő, két saját gyermeket nevelő, hívő nők kívánták gyarapítani gyermekeik számát a 2001. évi adatfelvétel idején. 


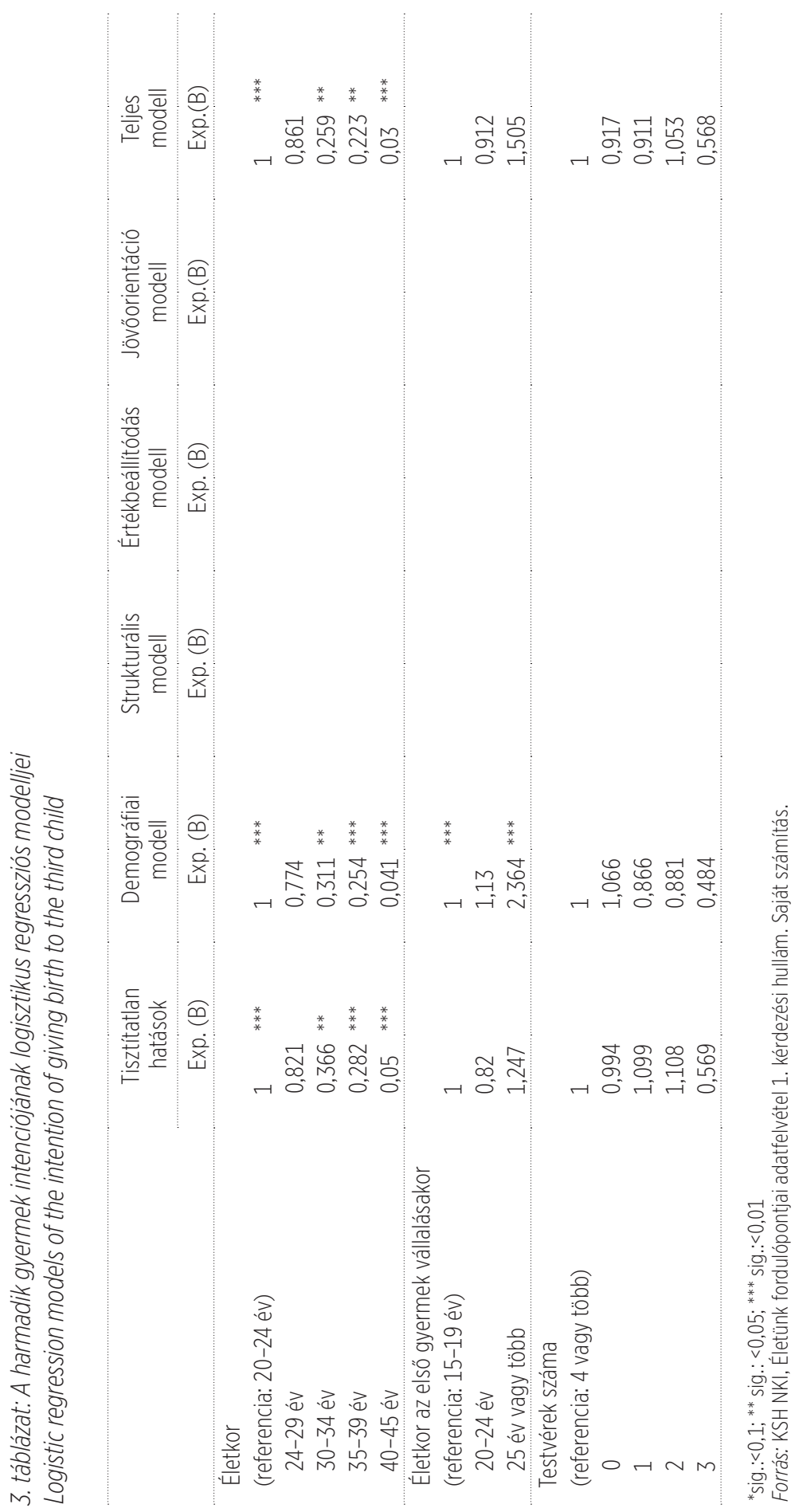




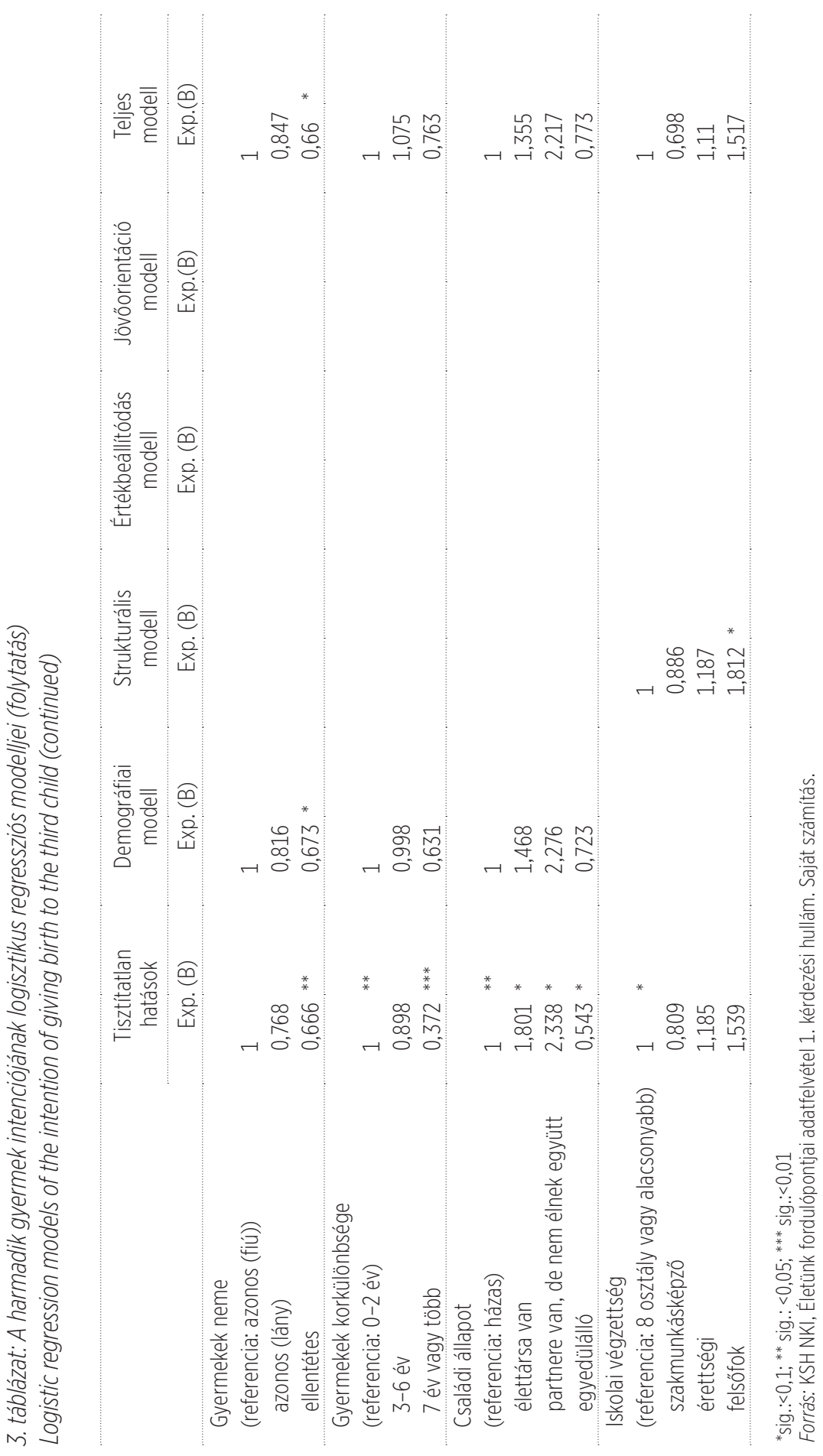




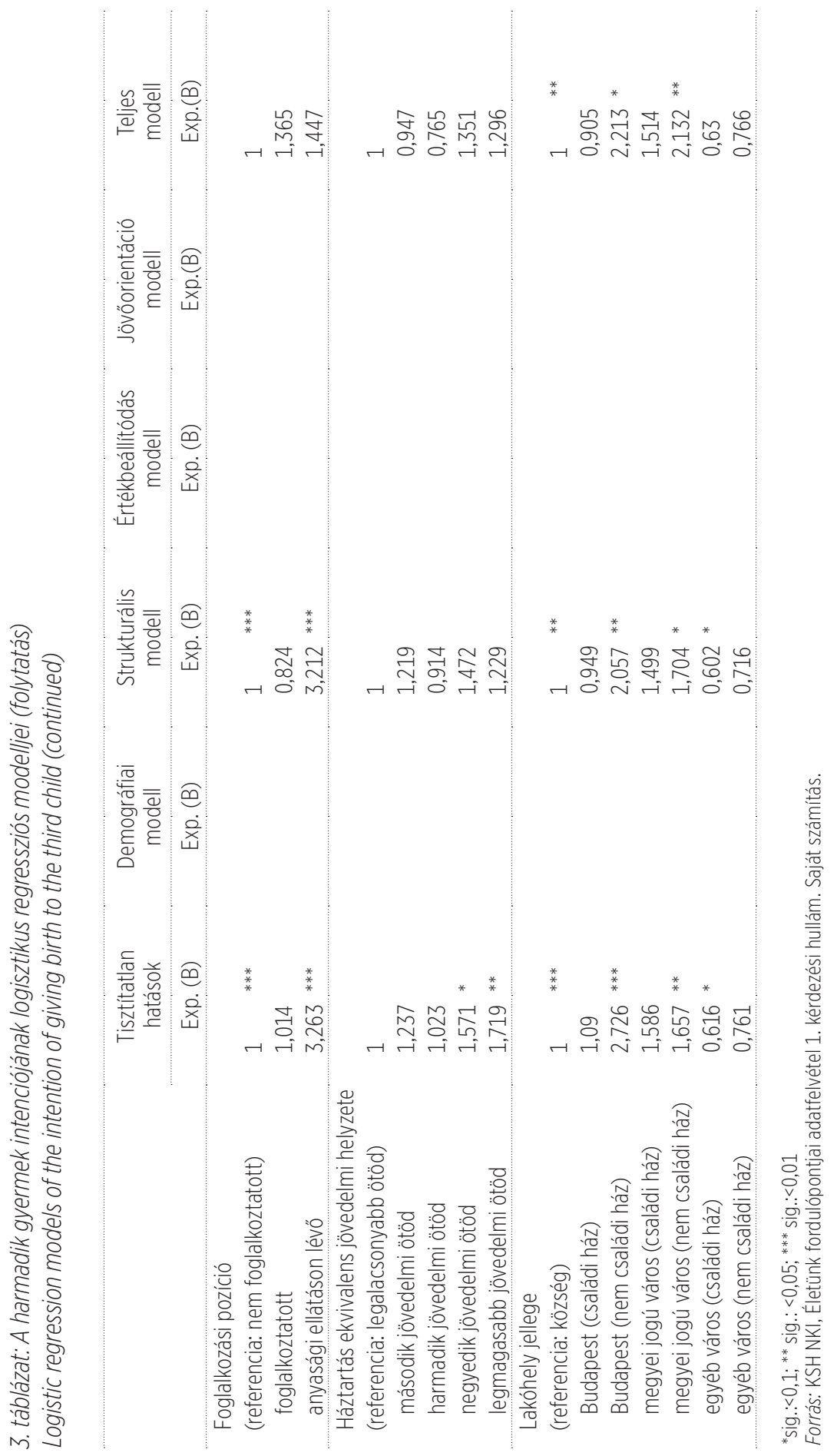




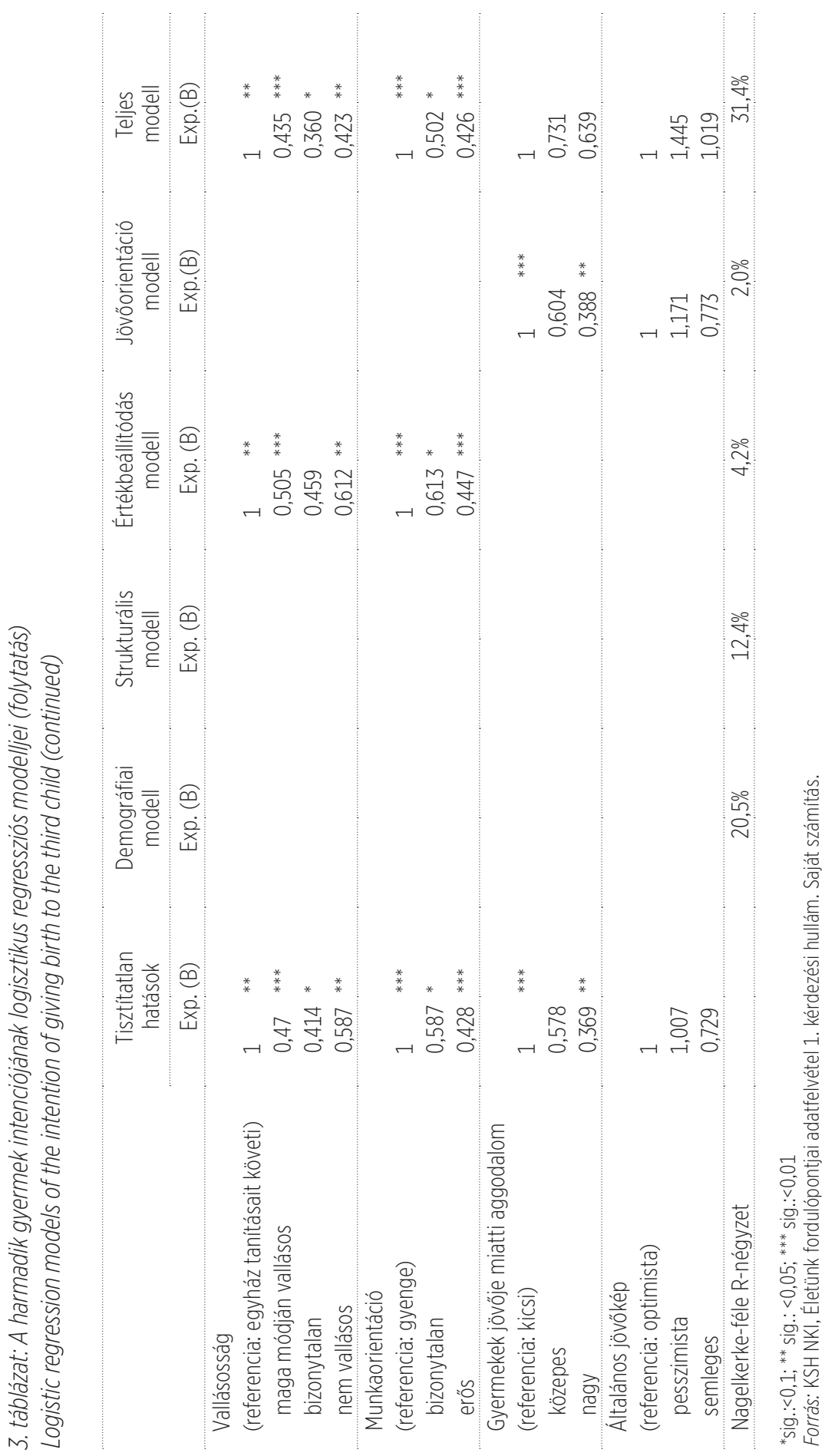




\section{ÖSSZEGZÉS}

Tanulmányomban a harmadik gyermek vállalására irányuló intenció elemzését tüztem ki célul. A magyar társadalomban általánosan elterjedt kétgyermekes családmodell normájától eltérő viselkedés okait - több szempontú megközelítést alkalmazva - három tényező együttes hatásának eredményeként definiáltam. Elméleti következtetésekre alapozva az egyének objektív, strukturális helyzeteit, szubjektív értékrendjeit, valamint jövőre vonatkozó szemléletmódját jelöltem meg a harmadik utód megszületésére irányuló szándék indoklásaként.

Vizsgálatom rávilágított arra, hogy e faktorok együttesen 31,4\%-ban magyarázzák a harmadik gyermek-vállalás intenciójának szóródását, a kétezres évek elején két gyermeket nevelő magyar anyák közül azonban csekély hányad kivánt újabb gyermeknek életet adni. Összegzésképpen elmondható, hogy az ezredfordulót követően azok a 30 év alatti, egyház tanításait követő, azonos nemü gyermekeket nevelő nők szerették volna bővíteni családjukat, akik nagyobb településen (Budapesten vagy megyei jogú városban), nem családi házban éltek és a munka iránt kevésbé elkötelezettek. Mindezek következtében előzetes feltevéseim közül több hipotézisem igazolást nyert, ugyanakkor számos feltételezésemet megcáfolták az adatok. A demográfiai tényezőkre és az értékrendekre vonatkozó hipotézisek inkább teljesültek, míg a közgazdasági elmélet szerint felállított elképzelések esetében a változók iránya a várttal ellentétes volt, de nem szignifikáns.

Az eredmények alapján egyértelmủen állitható, hogy az egyének objektív, strukturális státuszai közül az anyák életkora, gyermekeinek neme és lakóhelyének jellege határozta meg érdemben a harmadik utód világrajövetelének szándékát, míg az értékrendekre utaló faktorok tekintetében mindkét változó (a vallásosság és a munkaorientáció) szignifikáns összefüggésben áll a harmadik gyermek vállalásának intenciójával. Elképzelésem harmadik elemét mindazonáltal empirikus tapasztalataim nem támasztották alá: a háztartásukban két saját gyermeket nevelő nők jövő iránti nézetei nem befolyásolják lényegesen gyermekszámuk gyarapodásának szándékát.

Az intenciót szabályozó paraméterek feltárása után felvetődik a kérdés, mennyiben járulnak hozzá az egyének objektív és szubjektív helyzetei - az anyák következő utódra irányuló szándékával kiegészülve - a gyermekvállalási magatartás tényleges gyakorlatához? Mennyiben segítik elő ezen tényezők a harmadik utód megszületését? E fennálló kérdésekre kutatásom folytatása ad majd választ. 


\section{IRODALOM}

Ajzen, Icek 1991: The theory of planned behavior. Organisational Behavior and Human Decision Processes, 50(2), 179-211.

Alich, David 2004: Das dritte Kind. Ein Vergleich zwischen Deutschland und Norwegen. http://www.demogr.mpg.de/publications/files/1893_1113579023_1_Full\%20Text.pdf.

Letöltve: 2017. 01. 10.

Andorka Rudolf 1987: Gyermekszám a fejlett országokban. Gondolat Kiadó, Budapest.

Andorka Rudolf 1990 [1988]: A népesedésre vonatkozó újabb szociológiai elméletek. In Hoóz István - Káposztás Ferenc (szerk.) Népesedési elméletek, újabb irányzatok. Tudományos szeminárium (Pécs, 1988. szeptember 23-24.). Janus Pannonius Tudományegyetem Közgazdaságtudományi Kar, Pécs, 107-114.

Andorka Rudolf 2006 [1986]: Bevezetés a szociológiába. Osiris Kiadó, Budapest.

Beck, Ulrich 2003 [1986]: A kockázat-társadalom. Út egy másik modernitásba. Andorka Rudolf Társadalomtudományi Társaság - Századvég Kiadó, Budapest.

Beck, Ulrich 2008 [1999]: Világkockázat-társadalom. Az elveszett biztonság nyomában. Belvedere, Szeged.

Beckman, Linda J. 1983: Communication, power, and the influence of social networks in couple decisions on fertility. In Bulatao, Rodolfo A. - Lee, Ronald D. (eds.): Determinants of fertility in developing countries. Volume 2. Fertility regulation and institutional influences. Academic Press, New York, 415-43.

Berinde, Diana 1999: Pathways to a third child in Sweden. European Journal of Population, 15(4), 349-378.

Blake, Judit 1966: The Americanization of Catholic Reproductive Ideals. Population Studies, 20(1), 27-43.

Blake, Judit 1968: Are Babies Consumer Durables? A Critique of the Economic Theory of Reproductive Motivation. Population Studies, 22(1), 5-25.

Bongaarts, John 1998: Fertility and reproductive preferences in Post-Transitional Societies. Population Council, Policy Research Division Working Paper, No. 114.

Bulatao, Rodolfo A. 1981: Values and disvalues of children in successive childbearing decisions. Demography, 18(1), 1-25.

Cseh-Szombathy László 2000: Lehorgasztott fejjel? A magyar pesszimizmusról. Válaszok Solymosi Frigyes körkérdésére. Magyar Tudomány, 45(1), 12.

Dányi Dezső 2000: Demográfiai átmenetek. (Valóság, tudomány, politika). Demográfia, 43(2-3), 231-251.

Fawcett, James 1983: Perceptions of the value of children: Satisfaction and costs. In Bulatao, Rodolfo - Lee, Ronald D. - Hollerbach, Paula E. - Bongaarts, John (eds.): Determinants of fertility in developing countries: A summary of knowledge, Part A. National Academy Press, Washigton D.C, 347-369.

Gyenei Márta 2008: A „stratégiai gyerek” - avagy miért növekszik nálunk a csecsemőhalandóság? http://nol.hu/archivum/archiv-508290-304622. Letöltve: 2017. 01. 19.

Hegedűs Rita 2007: Újabb adatok a magyar „egyházias vallásosság” társadalmi megjelenéséről. In Hegedűs Rita - Révay Edit (szerk.): Úton. Tanulmányok Tomka Miklós tiszteletére. Szegedi Tudományegyetem Vallástudományi Tanszék, Szeged, 283-296. 
Heiland, Frank - Prskawetz, Alexia - Sanderson, Warren C. 2008: Are individuals' desired family sizes stable? Evidence from West German panel data. http://citeseerx.ist.psu. edu/viewdoc/download?doi=10.1.1.367.2795\&rep=rep1\&type=pdf. Letöltve: 2018.11.30.

Hoem, Britta - Hoem, Jan M. 1989: The impact of the women's employment on second and third births in modern Sweden. Population Studies, 43(1), 47-67.

Hoem, Jan M. - Prskawetz, Alexia - Neyer, Gerda 2001: Autonomy or conservative adjustment? The effect of public policies and educational attainment on third births in Austria. Max Planck Institute for Demographic Research, Rostock, MPIDR Working Paper WP-2001-016.

Kamarás Ferenc 2001: A termékenység alakulása és befolyásoló tényezői. In CsehSzombathy László - Tóth Pál Péter (szerk.): Népesedés és népességpolitika. Századvég Kiadó, Budapest, 13-41.

Kluckhohn, Clyde 1951: Values and value-orientations in the theory of action: An exploration in definition and classification. In Parsons, Talcott - Shils, Edward A. Smelser, Neil J. (eds.): Toward a General Theory of Action. Harvard University Press, Cambridge, 388-433.

Kravdal, Oystein 1990: Who has a third child in contemporary Norway? A registerbased examination of sociodemographic determinants. Statistisk Sentralbyra, OsloKongsvinger.

Lesthaeghe, Ron - Moors, Guy (2000): Életpályaváltások és értékorientáció: szelekció és adaptáció. Demográfia, 43(4), 405-444.

Merton, Robert K. 1980 [1949]: Társadalomelmélet és társadalmi struktúra. Gondolat Kiadó, Budapest.

Miettinen, Anneli - Basten, Stuart - Rotkirch, Anna 2011: Gender equality and fertility intentions revisited: Evidence from Finland. Demographic Research, 24(20), 469-496.

Miller, Warren B. - Pasta, David J. 1995: Behavioural intentions: Which ones predict fertility behaviour in married couples? Journal of Applied Social Psychology, 25(6), 530-555.

Philipov, Dimiter - Testa, Maria Rita 2008: Why fertility intentions remain unrealised? A case study in Bulgaria. Előadásként elhangzott European Population Conference Barcelona, July 9-12. http://epc2008.princeton.edu/papers/80555. Letöltve: 2018.01.30.

Régnier-Loilier, Arnaud - Vignoli, Daniele 2011: Fertility Intentions and Obstacles to their Realization in France and Italy. Population, 66(2), 361-390.

Rinesi, Francesca 2009: Feconditá attesa e realizzata delle madri italiane. PhD thesis, La Sapienza, University of Rome.

Rosina, Alessandro - Testa, Maria Rita 2009: Couple's First Child Intentions and Disagreement: An analysis of the Italian Case. European Journal of Population (25), 487-502.

Rosta Gergely 2011: Vallásosság a mai Magyarországon. Vigilia, 76(10), 741-750.

Sauvy, Alfred 1963: Théorie générale de la population. Presses Universitaires de France, Paris.

Schoen, Robert - Astone, Nan M. - Kim, Young J. - Nathanson, Constance A. 1999:

Do fertility intentions affect fertility behaviour? Journal of Marriage and Family, 61(3), 790-799.

S. Molnár Edit 2010: Demográfiai eseményeket kísérő magatartási normák változásai. Statisztikai Szem/e, 88(3), 252-272. 
S. Molnár Edit 2011: A közvélemény gyermekszám-preferenciáinak alakulása Magyarországon az elmúlt évtizedekben. In Pongrácz Tiborné (szerk.): A családi értékek és a demográfiai magatartás változásai. KSH NKI Kutatási Jelentések, 91., Budapest, 69-94.

S. Molnár Edit - Dobossy Imre 2000: „Tradíciókövető” és „modernizálódó” szemléletmód a rendszerváltozás után jelentkező családi problémák érzékelésében. In Spéder Zsolt - Tóth Pál Péter (szerk.): Emberi viszonyok. Andorka Rudolf Társadalomtudományi Társaság - Századvég Kiadó, Budapest, 80-100.

S. Molnár Edit - Kapitány Balázs 2002: Gyermekcentrikus érzelmek és egyéni célok, vágyak viszonya. In Pongrácz Tiborné - Spéder Zsolt (szerk.): Népesség - értékek - vélemények. KSH NKI Kutatási Jelentések 73., Budapest, 55-74.

S. Molnár Edit - Pongrácz Tiborné 2002 [1996]: Közvélemény-kutatás népesedési kérdésekről - 1995. In Faragó Tamás (szerk.): Szerkezetek, folyamatok, összefüggések. Új Mandátum, Budapest, 386-397.

Spéder Zsolt 2003: Gyermeket vállalni - új strukturális körülmények között. In Spéder Zsolt (szerk.): Család és népesség - itthon és Európában. KSH NKI - Századvég Kiadó, Budapest, 86-112.

Spéder Zsolt - Kapitány Balázs 2007: Gyermekek: vágyak és tények. Dinamikus termékenységi elemzések. KSH NKI, Budapest

Spéder Zsolt - Kapitány Balázs 2014: A termékenységi szándékok és a gyermekvállalási gyakorlat kapcsolata. Egy európai összehasonlító vizsgálat tanulságai. Demográfia, 57(2-3), 137-181.

Statistics Sweden 2011: A third child - a new trend? https://www.scb.se/statistik/_ publikationer/BE0701_2011A01_BR_BE51BR1101.pdf Letöltve: 2018. 11. 19.

Testa, Maria Rita 2010: Child-number and child-timing intentions in a micro-macro European framework. Vienna Institute of Demography of the Austrian Academy of Science, Vienna, Demographic Research Papers (4).

Vajda Ágnes 1988: A demográfiai problémák filozófiai - társadalom-antropológiai összefüggései - egy értékelméleti hipotézis tanulságai. In Hoóz István - Káposztás Ferenc (szerk.) 1990: Népesedési elméletek, újabb irányzatok. Tudományos szeminárium (Pécs, 1988. szeptember 23-24.). Janus Pannonius Tudományegyetem Közgazdaságtudományi Kar, Pécs, 39-61.

van de Kaa, Dirk J. 1998: Postmodern fertility preferences: from changing value orientation to new behaviour. Working Papers in Demography, (74). https://openresearchrepository.anu.edu.au/bitstream/1885/41465/5/74.pdf Letöltve: 2018.11.30.

Weber, Max 1987 [1922]: Gazdaság és társadalom. A megértő szociológia alapvonalai. 1.kötet. KJK, Budapest.

Werner, Paul D. - Middlestadt-Carter, Susan E. - Crawford, Thomas J. 1975: Having a Third Child: Predicting Behavioral Intentions. Journal of Marriage and Family, 37(2), 348-358. Westoff, Charles - Potter, Robert G. - Sagi, Philip 1963: The Third Child: A Study in the Prediction of Fertility. Princeton University Press, Princeton, New Jersey.

Yavuz, Sutay 2006: Completing the fertility transition: Third birth developments by language groups in Turkey. Demographic Research, 15(15), 435-460. 


\section{FAMILY GROWTH INTENTIONS - THE INTENTION OF THE THIRD CHILD TO HAVE}

\section{ABSTRACT}

The study seeks to examine the process of parity-specific fertility decisions, and above all, to aim at a closer understanding of the intention to have the third child. The outlined theoretical framework and the empirical analysis can provide an explanation of which characteristics of women with two children affect the intention of bringing the third child into the world: How do the structural positions of persons (1), their values (2) and their future orientation (3) influence whether they want a third child or not? Using the logistic regression method a multivariate analysis has been carried out by the first (2001/2) wave of the socio-demographic data collection called "Turning points of our lives" of the CSO Population Research Institute. According to my results, women under the age of 30 - who follow religious principles, who bring up children with same sex, who live in a larger settlement (in Budapest or in a county town) not in a family house, who are less committed to work -, they would like to expand their families. As a result of this, many of my previous hypotheses have been proved, but many of my assumptions have been reversed. 